\title{
Appraisal of Community Forest Associations in Advancing Livelihood and Conservation Agenda. A Comparative Study of Urban and Rural Forests in Kenya
}

\author{
Victor Kiprotich Boiyo, Jane Mutune Mutheu, Kiemo Karatu
}

\begin{abstract}
The twin goals of participatory forest management as adopted by many developing countries are to foster sustainable forest management and to reduce poverty. In Kenya, various legal and policy reforms have been introduced and attempts have been made to devolve use and forest management rights to local communities. It remains debatable whether communities' participation has yielded the intended improvements in livelihood and good governance. It would be no exaggeration to say that the study of forests and rural community livelihoods has been central to the development of scholarship on impacts of PFM on livelihoods. Equally certainly, the interest in forests has generated a need to consider the same in the light of urban forestry. This study based on participatory forest management program (PFM) in Ngong' Road forest in Nairobi City County and Kiptuget in Baringo County Kenya was conducted with the aims of establishing factors motivating members' participation and identifying and describing the conservation and income generating activities undertaken and their effects on members livelihoods. Quantitative and qualitative data was collected through questionnaires, interview of key informants, focus group discussions and literature reviews. The results show that in both NRFA and KICOFA, factors related to perceived benefits in terms of economic, social, factors, forest products and services, appreciation of nature and conservation were motivations for participation. Further, the study realized that despite the fact that both CFAs had an array of IGAs aimed at supplementing their livelihoods and easing pressure on the forest, NRFA had made more significant progress in terms of realizing these activities as compared to KICOFA. It was further realized that though there was a general similar trend in terms of average earning from engaging in PFM, the study noted that in both KICOFA and NRFA, averagely $50 \%$ of the members were satisfied with the benefits. It was further observed that majority of members both in KICOFA and NRFA indicated that PFM has had large positive impact on their livelihood and thus their household were in a better position that before joining the CFA.
\end{abstract}

Index Terms - Appraisal, Participatory Forest management \& Community Forest Association.

Victor Kiprotich Boivo, Wangari Maathai Institute for Peace and Environmental Studies, University of Nairobi, Kenya

Jane Mutune Mutheu, Wangari Maathai Institute for Peace and Environmental Studies, University of Nairobi, Kenya

Kiemo Karatu, Department of Socilogy and Social Work, University of Nairobi, Kenya

\section{INTRODUCTION}

Participatory forest management is one of the approaches aimed at achieving sustainable development. As defined by WCED (1987), sustainable development is a kind of development aimed at meeting the needs of the present generation without compromising the future generation from meeting its needs. Its objectives is therefore to use the life support system in a way that will guarantee continuity through regeneration. This encompasses development to alleviate poverty and at the same time promote environmental conservation and management (Tesfaye, 2011). In the same breath, participatory forest management is aimed at preventing the degradation of forest resources while at the same time sustaining the livelihoods of Forest Adjacent Communities (Angelsen et al , 2014). In light of this, implementation of PFM requires a profound understanding of the place of forest resources in the livelihoods of forest dependent community and the role of forest-based activities in enhancing livelihoods and alleviating poverty.

A lot of research that has been done on forest and livelihoods globally and in Kenya has been hugely focused on rural livelihoods (Myhren, 2007), (Angelsen et al., 2014) . In recent amendments to the Kenyan forest legal framework, it was observed that there is need to broaden the scope and recognize the role of urban forestry and how they contribute to human livelihoods in the quest to foster sustainable management (GOK, 2016). Most of this studies particularly on sustainable natural resource use has revealed that in order to mitigate degradation and alleviate poverty, it is important to systematically consider the livelihood of the community that is depended to the resource (Ogada, 2012). With this understanding, implementation of any sort of community participation will take care both of community as well as environmental interests. In light of this participation should be understood and employed in various ways ranging from instrumentalism aimed at achieving efficiency and empowerment where the process is controlled by the community (Tesfaye et al, 2017)

\section{SUSTAINABLE LIVELIHOODS}

There has been a longstanding debate on the outcome of the configuration of sustainable development in the context 
of environment, poverty and sustainability. As a result many scholars have come to suggest that sustainable development requires increasing the capacity of people to control their future. This can only be achieved through strengthening capacity, supporting equity, and fostering empowerment (Tesfaye et al., 2017). According to Conway and Chambers 1992, livelihood comprises the capabilities, assets and activities required for a means of living.

Scholars have identified five types of livelihood assets also called capitals. These include natural which are also called environmental resources, physical like infrastructure, human capital which is labor, financial capital which refers to cash, and social capital which include community and related networks and relationships (Ellis, 2000). Institutions, policies and organizations play a key role in determining access to assets, returns to livelihoods strategies, and terms of exchange between different types of capital (DFID, 1999).

Several disciplines, including the development fields, sociology, environmental studies and economics which most of them have been modelled around rural livelihoods have appreciated that forests and forest products play a key and fundamental role in the survival and the well-being of rural poor (Angelsen et al., 2014). According to Chao 2012, approximately 350 million of the world's poorest people mostly in developing countries entirely depend on forests for their survival. In a study done in South Africa by Shackleton in 2004, it was found out that rural populace engaged in multiple and diverse portfolios and strategies including farming and forest resources to support their livelihoods. In light of this, it is important to note that there is very scarce literature and information on how the case has been in relation to urban forests and livelihoods.

As is the case with other developing countries, a large population of Kenyans particularly in rural areas live adjacent to the forest and are dependent on the forest resource for their livelihood. According to Wass 1995, about 2.9 Million people in Kenya, live adjacent to the forest resources and depend on it for goods and services including medicines, fuelwood, fodder, pasture, food, water etc. . According to Mungai et al 2011 in a study done in Aberdare forest, it was observed that the forest adjacent community through CFAs engaged in intensive farming, business activities and collection of forest for fodder, water, and firewood. In another study done by Mutune in 2015 in Eastern Mau Forest on livelihood impacts of Participatory forest management, it was observed that implementation of PFM had introduced new opportunities to the community and benefits which include seedling production, tree planting and plantation maintenance and bee-keeping which were all funded by donors.

\section{THEORETICAL FRAMEWORK}

According to DeCaro and Stokes (2008, it is observed that PFM will only be successful when autonomy of local stakeholders is acknowledged. The study further emphasized that this is possible by enhancing democratic procedures, key among them inclusion in management decisions, legitimized access and benefit sharing. Many scholars have termed this as self- determination theory which is the very premise of motivation for participation. In practice, Self-determination theory holds the view that there exists varied types of motivation that are determined by the individuals level of autonomy (Bidii and Ngugi, 2014). The motivation are expressed in terms of individuals' reasons for doing the activity and the degree to which these reasons align with self-held values. According to KFS 2009, the motivation to participate in PFM is driven by anticipated benefits emanating from participation (KFS, 2009). In another study done by Koech et al 2009, it was observed that one of the major objective for involving communities in forest management is to foster sustainability. It was clear that the motivation of most members of forest associations was the opportunity to utilize forest resources without the existing Government restrictions and only a few had perceived forest conservation as a priority (Koech et al , 2009).

In considering the PFM activities and its effects, the study adopted a motivation, activities and effect model as shown below;

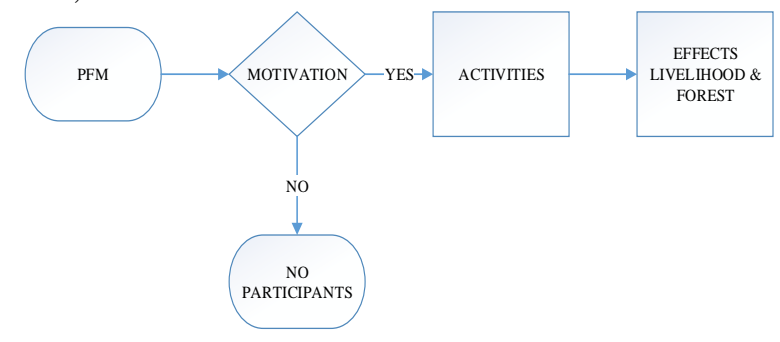

In the model, motivation refers to drivers of why members chose to participate in PFM. These include economical gain, sports, cultural values, etc. Activities, refers to both forest based and economical based activities undertaken by CFA members as a group or as individuals in the forests as per the granted user rights while effects refers to the outcome realized on members livelihood as a result of engaging in the activities

\section{MATERIALS AND METHODS}

This research was conducted in Ngong' Road forest in Nairobi City County and Kiptuget forest in Baringo-a section of Mau Complex, sites which were purposefully selected to represent urban and rural forests in Kenya respectively. The data was collected over a period of 3 months by the Researcher assisted by a Research Assistant. To respond to this objective, primary data was sourced through questionnaires administered to CFA members. A total of 83 and 125 members of NRFA and KICOFA respectively participated in the study. Further to this, interviews with key informants including Forester in charge as well as the Chair of the CFA were conducted using design interview schedule. The researcher also collected data through observation and focus group discussions. Qualitative and quantitative collected was analyzed using SPSS and cross tabulation, and frequencies were used in manipulating quantitative data. 


\section{RESULTS AND DISCUSSION}

Motivation to participate

There are a lot of factors that motivate members to join CFAs and participate in forest management. The study sought to find out what motivates community members in rural and urban forest to engage in PFM and the findings are as shown in the table 1

From the study it was realized majority of members of NRFA at $35.00 \%$ were motivated by economic factors to engage in PFM. On the other hand, majority of members of KICOFA at $40.00 \%$ were motivated by the need to extract forest products. It is also interesting to note that $18.00 \%$ of the members of NRFA were motivated by appreciation of nature compared to $5.00 \%$ of members in KICOFA while $15.00 \%$ of NRFA members were motivated by the need to conserve the forest compared to $5.00 \%$ of the members of KICOFA.

Table 1: Factors motivating members to engage in PFM

\begin{tabular}{|c|c|c|}
\hline FACTOR & NRFA & $\mathrm{KICOF}$ \\
\hline Economic factors & $35 \%$ & $20 \%$ \\
\hline $\begin{array}{l}\text { Extract } \quad \text { forest } \\
\text { products }\end{array}$ & $7 \%$ & $40 \%$ \\
\hline Forest services & $15 \%$ & $10 \%$ \\
\hline Social factors & $10 \%$ & $20 \%$ \\
\hline $\begin{array}{l}\text { Appreciation } \\
\text { nature }\end{array}$ & $18 \%$ & $5 \%$ \\
\hline Conservation & $15 \%$ & $5 \%$ \\
\hline
\end{tabular}

From the findings it is established that members in rural and urban forest in Kenya are motivated differently to participate and engage in PFM. It is generally observed that as members in rural forest are motivated by the forest products as primary source of livelihoods, members in urban forests were motivated by making economic gains not necessarily direct dependence on forest products but secondarily through market driven services like ecotourism. It was further realized that majority of city dwellers are not only conservation sensitive but also have a consideration of appreciating nature. On the other hand, the rural community are much focused on benefitting directly from the forest in terms of products to meet their needs. This is a more instrumental value of the forest which involves food, water, shelter and other physical needs which can directly be acquired from the forest. It can be postulated that city dwellers value forest for what it is, offering green space where they can relax and engage in recreation activities due to limited space for such in urban areas. It can be argued that this difference in motivation is a as result of several factors among them livelihoods as well as socioeconomic and sociocultural factors of the community. It is also postulated that these motivations is a key driver in the user rights of the CFAs as well as the activities members engage in either in conservation or income generation.

The study found out that there was a positive relationship between socioeconomic status and the choice of activity or user group. It was noted that members with similar or almost the same social status opted for same or similar activity or user group as highlighted in table .2.

Table 2: NRFA and KICOFA User Group

\begin{tabular}{|c|c|c|}
\hline USER RIGHT & NRFA & FICO \\
\hline Grazing & $0.00 \%$ & $9.6 \%$ \\
\hline Firewood Collection & $\%$ & $0.00 \%$ \\
\hline PELIS & $8.30 \%$ & $\%$ \\
\hline Tree Nursery & $\%^{20.30}$ & $0.00 \%$ \\
\hline Bee Keeping & $\%$ & $0.00 \%$ \\
\hline Eco-Tourism & $\%^{14.00}$ & $0.00 \%$ \\
\hline Sporting/Leisure/Clu & $\%^{15.70}$ & $0.00 \%$ \\
\hline
\end{tabular}

From the study is observed that at KICOFA, a majority of members at $90.40 \%$ indicated that PELIS was the most important use right. Despite a range of other available use rights in the forest like ecotourism, bee keeping and grazing, all the members who participated in the study only settled on either PELIS at $90.40 \%$ or grazing at $9.60 \%$ as the most important use right in the forest. It was interesting to note that none of the members indicated that the most important user right was firewood collection, tree nursery establishment, bee keeping or even sporting or leisure. On the other hand, the study found out that in NRFA, there was a relatively sizeable interest in four use rights rated as most important to members. These include firewood collection at $15.30 \%$, PELIS at $8.30 \%$, Tree nursery at $20.30 \%$, bee keeping at $26.50 \%$, Ecotourism $14.00 \%$ and sporting and leisure activities at $15.70 \%$

This study confirms that in rural areas, agriculture still remains the major source of livelihoods for forest adjacent communities. It thus indicates that implementation of PFM in rural areas should be intertwined with sustainable agriculture. The study agrees with the a study done by (Phiri, 2009) in Ethiopia where it was confirmed that agriculture was the most important livelihood activity among local people around Dambwa Forest Reserve, which involved crop farming and keeping livestock for home consumption and for sale. Owing to the operation of PELIS, the end product of the activity is establishment of forest plantation. Consequently the research revealed that the members of the community were worried on the source of livelihood when the entire available arable land will be fully covered with plantation. This was a real concern in the study and thus there is need to find a way that PFM can continue to support the livelihoods in longer term. As compared to NRFA, it can be observed that CFAs in urban areas have more diverse areas of interests giving rise to diverse user rights and diverse sources of livelihoods. In addition to this, it is evident that there is more optimal utilization of forest by the community in so far as meeting their livelihoods is concerned. In addition to this, diversity of use rights and source of livelihoods will bring on board 
diverse community members to participate. As a result there are higher chances that in the long run, the engagement will realize both forest conservation as well as livelihood objective of PFM since the resulting diversity reduces pressure on specific part of the forest resource.

\section{FOREST PRODUCTS}

The study found out that both Kiptuget and Ngong' road forest were endowed with both wood and non-wood products that play a key role in supporting livelihoods as indicated table 3

Table 3: Forest Products derived by NRFA and KICOFA members

\begin{tabular}{lll}
\hline FOREST & Wood Products & Non Wood Products \\
\hline Kiptuget Forest & Indigenous wood products & Water \\
& Plantation wood products & Farming products (PELIS) \\
& & Grazing resources \\
& & Honey \\
& & Bamboo \\
& & Medicinal herbs \\
Ngong' Road Forest & Indigenous wood products & Fruits and vegetables \\
& Plantation wood products & Grazing \\
& & Medicinal herbs \\
& & Honey \\
& & Weaving reeds \\
& Farming products \\
\hline
\end{tabular}

The study further established that out of the members who collected products from the forest, majority of the members collected more than one kind of a product. The study sought to find out which among the products collected by members was more important for their livelihoods and the results are as shown in table 4;

Table 4: Most Important product collected by NRFA and KICOFA members

\begin{tabular}{lcccccc}
\hline & Firewood & Fodder & Food materials & Poles & Timber & None \\
\hline NRFA & $43.40 \%$ & $9.20 \%$ & $28.90 \%$ & $2.60 \%$ & $2.60 \%$ & $13.20 \%$ \\
\hline KICOFA & $0.00 \%$ & $0.00 \%$ & $100.00 \%$ & $0.00 \%$ & $0.00 \%$ & $0.00 \%$ \\
\hline
\end{tabular}

From the study, it was realized that $100.00 \%$ of the members of KICOFA indicated that food materials were the most important product collected from the forest. The study further established that members in KICOFA benefited not only from the PELIS harvests but also wild fruits, vegetables, water and pasture for their animals which in a bigger way constitute their subsistence. On the other hand, the study found out that in Ngong' Road Forest majority of the members who collected products considered firewood as very important at $43.40 \%$, food materials at $28.90 \%$, fodder at $9.20 \%$ and poles at $2.60 \%$. The study further noted that $13.20 \%$ of the members of NRFA noted that none of the forest products was more important compared to $0.00 \%$ of the members of KICOFA who felt the same.

Forest products is a key component of livelihoods for forest adjacent community. From the findings of this study, it is established that despite the fact that members both in KICOFA and NRFA make use of various forest product, it was realized that high rate of members of KICOFA are users of forest products as compared to NRFA members. It can be argued that the livelihood of rural community in Kenya is hugely supported by products derived from the forest. This is evidenced from the fact that majority of the members of KICOFA are deriving food materials, vegetables, fruits and water from the forest. Just like many other studies have found out, the usual valuation of forests most of the times focusses on the commercial timber values and ignores the importance of other forest uses such as the extraction of non-timber forest products and water catchment. This is a phenomenon that has encouraged logging in both KICOFA and NRFA over the often more sustainable extraction of non-timber forest products and other economically relevant services. In both KICOFA and NRFA, besides the KFS commissioned logging it was realized that there were cases of illegal logging. It is however worth noting that there were more cases of illegal logging in Kiptuget than in Ngong Road forests.

\section{FOREST SERVICES}

The study further sought to find out the whether the forest adjacent community in Kiptuget and Ngong' Road forest were in a way benefitting from the forest in form of services. It was established CFA members both in NRFA and KICOFA were benefitting from forest services in one way or another. In establishing the nature of the services, it was realized that majority of members of KICOFA at $54.40 \%$ were enjoying 
socio-cultural nature of service from the forest while majority of members at NRFA at $37.10 \%$ were enjoying economic nature of service from the Ngong' Road Forest as shown in table 5

Table 5: Nature of forest services enjoyed by members of NRFA and KICOFA

\begin{tabular}{cccccc}
\hline & Recreation & Economical & Religious & Social cultural & Total \\
\hline NRFA & $21.30 \%$ & $37.10 \%$ & $27.20 \%$ & $14.50 \%$ & $100.00 \%$ \\
\hline KICOFA & $10.40 \%$ & $10.00 \%$ & $25.20 \%$ & $54.40 \%$ & $100.00 \%$ \\
\hline
\end{tabular}

From the study, it is realized that members in Ngong' Road forest were benefitting more on the economical related services of the forest at $37.10 \%$ as compared to Kiptuget forest at $10.00 \%$. On the other hand, socio cultural benefits ranked high in Kiptuget at $54.40 \%$ as compared to NRFA at $14.50 \%$. According to (Matiru, 2002), many tradition indigenous forests are traditionally important for cultural ceremonies and as sacred sites to local communities. It can be suggested that the findings of KICOFA in this study confirms this observation. In this case, the study found out that the Kalenjin Community in Kiptuget forests considered some trees deep in Kiptuget forests as sacred. In addition, the forests had caves where young men undergoing circumcision rites were supposed to live. Additionally, certain part of the forest was considered sacred groves with the felling of trees and the collection of forest products prohibited or strictly regulated.

In relation to recreation, the study found out that NRFA registered higher level of recreational benefits at $21.30 \%$ as compared to KICOFA at $10.40 \%$. The study realized that Ngong' Road forest had a whole user group registered for recreational purposes. This was horse racing and cycling. As a result of this, Ngong' Road forest has become a center of attraction for major marathons and walk events in Nairobi city. During the study, it was established that the forest has played host to several marathons and walks organized by different public and private organizations for example it was realized that the forest has played host for Starehe Girls' Centre annual walk, Kenya national marathon for the disabled, Kenya national jockey leagues and championships among many others. The study found out that these events had raised huge financial resources to the forest that had facilitate a lot of programmes being undertaken by the CFA among them establishment of nature walk and electric fencing of the sanctuary.

On the other hand, the study found out that despite few athletes who make use of forest terrain for training in Kiptuget, there was no elaborate and organized use of the forest in terms of leisure, sports and recreation. It was however realized that given its terrain, Kiptuget forest has a potential to be one of the best high altitude training center for athletes.

In regard to religious benefit, the study established that in NRFA, $27.20 \%$ of the members benefitted from the forest. It was established that the forest was used as a place where individuals or groups went for prayers. It was further noted that NRFA charged prayer groups from the Nairobi and its vicinity to conduct prayers in the forest. This is another avenue that the CFA raised money to fund its activities. At the time of research, it was established that NRFA had invested in a hall, where groups could meet, benches and open spaces to facilitate prayer groups as well as other religious events like weddings. On the other hand, the study found out that despite the fact that members of KICOFA and other groups made use of the forest for Christian as well as traditional prayer rites, there was no investment had been made to enhance this and there was no clear and elaborate way of realizing any economic benefit from the opportunity.

\section{INCOME GENERATION ACTIVITIES}

The study established that the level of dependence on the forest both in KICOFA and NRFA varies with the socio-economic status of a household and interests and needs of individuals and communities. Given that the forest provides environmental, socio- economic and ecological benefits it was established that the overdependence had overwhelmed the ecosystem as the demand for goods and services from the forest wasn't sustainable hence making it of paramount importance to consider that alternative livelihood sources and IGAs adopted by members both in KICOFA and NRFA.

From the management plan and agreement signed between NRFA and KFS, it was realized that the parties agreed that community programme will be structured in a way that there will be community resource management which will reduce pressure on forest products for the long term sustainable management of the forest by promoting alternative sources through Income Generating Activities (IGAs). It was further noted that it was required that the CFA would undertake several IGAs including beekeeping, charcoal briquette making, as part of non-wood products, poultry keeping, and zero grazing, among many others. As such it was agreed that one of the management objectives of the CFA was to strengthen the CFAs through adequate capacity building on agribusiness enterprises and IGAs. In order to achieve this, the framework noted that the entity will endeavor to involve community in high investment ventures such as eco-lodges, identify suitable investments and negotiate for percentages between CFA and investors including marketing cost, promote extension services to the community to increase knowledge flow, train the CFA and user groups in sustainable forest management business/entrepreneurships and negotiations, train the CFA basic skills in budgeting, proposal writing and basic accounting and invite officials from the youth and women's fund to brief the CFAs on how to access their funds.

Just as the case was in NRFA, the study established that Kiptuget forest was under the same pressure for wood and non-wood products to support the community livelihood. The study established that just like NRFA one of the major objectives was establishment of KICOFA was to promote the 
establishment of on-farm and off-farm income generating activities (IGAs) among the community members. In highlighting the roles of its stakeholders, KICOFA indicated that NEMA and the national government was to play a key role in advising on the area of IGAs.

The researcher evaluated the level of implementation of the laid down frameworks towards realizing the goal of IGAs. This was done using a scale of 0-5 (where $0=$ nothing done, $1=$ documentation done, $2=$ documentation and contacts with partners done, 3=ground implementation screening done, $4=$ piloting done and 5=fully implemented) and the findings are as shown in table 6;

Table 6: Evaluation of Strategies to enhance IGAs in NRFA and KICOFA

\begin{tabular}{|c|c|c|}
\hline \multirow[t]{2}{*}{ Item } & \multicolumn{2}{|c|}{$\begin{array}{c}\text { Level } \\
\text { Implementation }\end{array}$} \\
\hline & NRFA & KICOFA \\
\hline $\begin{array}{l}\text { Involve community in high } \\
\text { investment ventures such as } \\
\text { eco-lodges }\end{array}$ & 3 & 1 \\
\hline $\begin{array}{l}\text { Identify suitable investments } \\
\text { opportunities }\end{array}$ & 4 & 1 \\
\hline $\begin{array}{l}\text { Negotiate for percentages } \\
\text { between CFA and investors } \\
\text { including marketing cost }\end{array}$ & 1 & 0 \\
\hline $\begin{array}{l}\text { Promote extension services to } \\
\text { the community to increase } \\
\text { knowledge flow }\end{array}$ & 5 & 4 \\
\hline $\begin{array}{l}\text { Train the CFA and user } \\
\text { groups in sustainable forest } \\
\text { management business }\end{array}$ & 2 & 0 \\
\hline $\begin{array}{l}\text { Train the CFA and user } \\
\text { groups in entrepreneurships and } \\
\text { negotiations }\end{array}$ & 2 & 1 \\
\hline $\begin{array}{l}\text { Train the CFA basic skills in } \\
\text { budgeting, proposal writing and } \\
\text { basic accounting }\end{array}$ & 3 & 0 \\
\hline $\begin{array}{l}\text { Invite officials from the youth } \\
\text { and women's fund to brief the } \\
\text { CFAs on how to access their } \\
\text { fund }\end{array}$ & 4 & 1 \\
\hline Total & 24 & 8 \\
\hline
\end{tabular}

From the findings, it was realized that NRFA had successfully initiated actions in all the eight areas that relate to IGA as highlighted in the framework. It was observed that the CFA had successfully implemented extension services and invitation of youth and women funds to meet their members. On the other hand, the study found out that KICOFA had not done anything on the three areas of IGA including training CFA on basic skills in budgeting, proposal writing and basic accounting, training on sustainable forest management business and negotiation of percentages between CFA and investors.

It can be argued that NRFA had done much better in optimizing the opportunities that arise from IGA in PFM. The study revealed that NRFA had made huge progress in terms of helping members to make use of the available opportunities. As compared to KICOFA which very little had been done in this direction, it can be argued that this is the explanation as to why NRFA is registering high rate of members benefitting from economical services of the forest as compared to members of KICOFA. In general thus, it is observed that far and beyond basic livelihood, CFAs in urban areas have made more progress in enhancing IGAs to support the community members as compared to CFAs in rural areas

\section{FOREST CONSERVATION ACTIVITIES}

According to the objectives that informed the formation of both NRFA and KICOFA, the study found out from the management agreement as well as the management plans that one of the key objective was to not only contribute poverty reduction, create employment, improve livelihoods through sustainable use but also to contribute to the conservation and management of forests and trees. The study further established that majority of CFA members both in KICOFA and NRFA participated in forest conservation related activities. It was realized that $85.50 \%$ of members of NRFA indicated that they participate in forest conservation activities while $14.50 \%$ indicated that they did not. On the other hand $85.60 \%$ of KICOFA members indicate that they participate in forest conservation activities while $14.40 \%$ do not.

From these findings, it is observed that indeed majority of CFA members both in KICOFA and NRFA are not only engaged in IGAs but are also engaged in forest conservation activities. It is observed that members are directly engaged in activities ranging from establishment of nurseries, soil conservation, silvicultural operations, forest protection activities like firefighting and monitoring and evaluation. It was interesting to note that members of NRFA were also engaged in clean-up activities.

While conducting these activities, it was also realized that NRFA had more partners where they engaged in joining activities. It was observed that NRFA conducted regular clean-up of the forests along Ngong' Road and were joined by several other players among them Kenya Wildlife services, schools, Nairobi City County, Universities and Nairobi Business Community. Contrary to this, KICOFA had no partnership and no record of working with other stakeholders apart from KFS. This was the case despite the fact that several organizations had installations within the zones that KICOFA undertake their activities. For example several Kenya media station have installed their airwave instruments in KICOFA forests and yet no partnership with the community had been established.

Further to this, the researcher sought to evaluate the level of implementation of the laid down management actions towards realizing forest conservation and sustainable use. 
This was done using a scale of 0-4 (where $0=$ nothing done, $1=$ documentation done, $2=$ documentation and contacts with partners done, 3=ground implementation screening done, $4=$ piloting done and $5=$ fully implemented) and the findings are as shown in table 7

Table 7: Level of implementation of Forest Conservation activities in NRFA and KICOFA

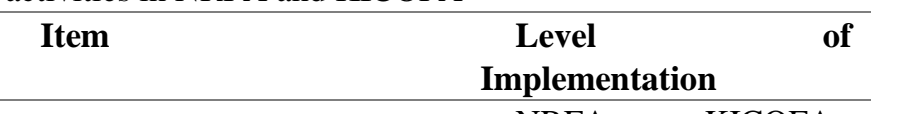

\begin{tabular}{|c|c|c|}
\hline & NRFA & KICOFA \\
\hline $\begin{array}{c}\text { Joint study on forest } \\
\text { biodiversity (flora and fauna) }\end{array}$ & 5 & 5 \\
\hline $\begin{array}{l}\text { Mapping of threatened forest } \\
\text { species }\end{array}$ & 4 & 2 \\
\hline \begin{tabular}{lrr}
\multicolumn{1}{c}{ Update } & forest & database \\
regularly from information \\
from relevant
\end{tabular} & 4 & 3 \\
\hline
\end{tabular}

\begin{tabular}{lll}
\hline $\begin{array}{l}\text { Capacity build community } \\
\text { on energy conservation }\end{array}$ & 5 & 1 \\
\hline $\begin{array}{l}\text { Encourage the use of } \\
\text { alternative renewable sources } \\
\text { of energy, e.g. solar, biogas, }\end{array}$ & \\
Train the CFA and user & 5 & 5 \\
groups in sustainable forest \\
management
\end{tabular}

\begin{tabular}{lll}
$\begin{array}{c}\text { Establish tree nursery and } \\
\text { participate in silvi-ciltural } \\
\text { activities }\end{array}$ & 5 & 5 \\
\hline Engage in joint monitoring & 5 & 3
\end{tabular}
and evaluation

$\begin{array}{lll}\text { Total } & 37 & 25\end{array}$

In conservation activities the study realized that majority of members in NRFA at $84.30 \%$ draw some income in engaging in some conservation activities. The study realized that these are scenarios whereby the KFS and CFA projects take in CFA members as laborers who work for a wage. Some of this activities enclosing tree nursery establishment, bush clearing, cleaning programmes, and fencing of the forests among many others. On the other hand, the study revealed that this is not the case in KICOFA as it was realized that $98.40 \%$ of members do not receive any income from participating in these activities. The same case was realized in the areas where KFS AND CFA engaged in joint projects. It was noted that in both NRFA and KICOFA although they engaged in joint projects with KFS, they did not receive any share of the benefit from this ventures. Ventures of establishment of nurseries as well as plantations were jointly done by both CFA and KFS but when it came to harvesting and tendering the study realized that the CFAs did not have any say. It was established that majority of members in NRFA at $97.30 \%$ and majority of members in KICOFA at $97.50 \%$ were not satisfied with the benefit sharing mechanism in place. It was noted that despite the existence of management agreement and plan, members could still have to pay to access some benefits and use rights from the forest.

From the findings, it is noted that the findings of this study concur with Sebele (2010) who indicates that the benefit sharing plan in implementation of PFM is a vital instrument in making sure that project beneficiaries find a real incentive in conserving natural resources, while promoting their own livelihoods, economically.

\section{CONCLUSIONS AND RECOMMENDATION}

Forests and community livelihood dynamics in rural and urban forests in Kenya are not the same. Generally, the study established that both urban and rural forest play a key role in in community livelihoods. The study realized that socioeconomic factors play a key role in determining the motivation as well as the use right the community apply for. The existing major difference was that KICOFA had a more homogenous group of members with almost the same source of livelihood while on the other hand NRFA had a diverse and heterogeneous group members with diverse and varied source of livelihood. This directly impacted on the nature of use rights whereby all the KICOFA members were registered for PELIS while members of NRFA were almost equally spread different user groups.

The study further realized that maturity of members of KICOFA were motivated by the need to extract forest products while majority of the members of NRFA were motivated by the need to derive economic benefits. In regards to forest services, it was established that majority of NRFA members were inclined to economic nature of the services while majority of their counterparts derived more on the socio cultural nature of services. In this regard, the study established that NRFA had performed better in terms of equipping members to make use of IGAs opportunities available in PFM as compared to KICOFA. This included networking with financiers, training on entrepreneurship, establishing markets and exposing members to sustainable investment ventures. As a result, the study found out that majority of members were deriving more financial benefit as compared to their counterparts in KICOFA.

The study further found out that NRFA was receiving more technical and financial support as compared to KICOFA. Technically, majority of members of NRFA had gone through training on PFM as well as IGA, while financial support had come from donors as well as the activities and ventures of the CFA. On the other hand, apart from training form KFS, KICOFA members had not received any other training and no financial support.

Forest conservation activities is one of the key areas and mandates of CFA. The study found out that both NRFA and KICOFA were engaged in forest conservation activities. It was however noted that NRFA had established more elaborate way of doing this as well as partners. For instance the study realized that CFA regularly led other stakeholders including KWS, KTB, Schools, Universities and Nairobi Business Community in major clean up initiatives within and without the forest. It was also realized that several members of NRFA undertook some forest conservation activities mount by KFS and were deriving wages. In most of the joint 
projects, majority of the members both in KICOFA and NRFA indicated that they were not satisfied with the benefit sharing.

In light of the afore mentioned it is recommended that;

a) The PFM stakeholders led by KFS should invest on research to identify ways and means necessary to inform diversification of forest livelihoods in rural forests in Kenya

b) There is need for forest stakeholders to invest in training CFA members and leaders particularly in rural areas on entrepreneurship in order to enhance maximizing of the available opportunities in PFM

c) KFS and other PFM stakeholders should invest in building technical, financial and networking capacity of CFAs particularly in rural areas. This will be critical in opening up areas of investments and exposing the CFAs to potential sustainable forest investment ventures and investors.

d) The legal and regulatory framework should be reviewed to reflect important subject on benefit sharing. This should be structured in a way that revenue from the forest benefits the community e.g. establishment of infrastructure, social amenities, supporting social groups etc. This will play a key role in enhancing the benefits of participation thus enhancing engagement.

\section{REFERENCES}

[1] Agrawal, A. and Ribot, J. C. (1999). Accountability in decentralization: a framework with South Asian and West African cases. The Journal of Developing Areas, 33(4), 473-502. https://doi.org/10.2307/4192885

[2] Angelsen, A., Jagger, P., Babigumira, R., Belcher, B., \& Wunder, S. (2014). Environmental Income and Rural Livelihoods: A Global-Comparative Analysis, https://doi.org/10.1016/j.worlddev.2014.03.006

[3] Bidii, H. K., and Ngugi, P. K. (2014). Challenges Impeding The Effective Implementation of Community-Based Natural Resource Management Projects in Kenya: A Case Study of Mji Wa Huruma Village in Nairobi, Kenya. International Journal of Social Sciences Management and Entrepreneurship, 40(1(2):141-173, August 2014), 172. Retrieved from http://www.emeraldinsight.com/10.1108/14777830710778292

[4] DeGeorges, P. A., \& Reilly, B. K. (2009). The realities of community based natural resource management and biodiversity conservation in Sub-Saharan Africa. Sustainability, 1(3), 734-788. https://doi.org/10.3390/su1030734

[5] KFS. (2009). Making Participatory Forest Management work in Kenya Policy Brief.

[6] Koech, C., K., Ongugo, P. O., Mbuvi, M. T. E., and Maua, J. O (2009). Community Forest Associations in Kenya: challenges and opportunities. Kenya Forestry Research Institute.

[7] Kosgey, B. A. (2015). An Assessment of the Implementation of Participatory Forest Management (PFM) by Ngong Road Community Forest Association (CFA) in Nairobi County, Kenya: Unpublished Thesis

[8] Matiru, V. (2002). Forest Landscape Restoration Kenya Country Report, (May).

[9] Mutune, J. M., Wahome, R. G., \& Mungai, D. N. (2015). Local Participation in Community Forest Associations : A Case Study of Sururu and Eburu Forests , Kenya. International Journal of African and Asian Studies, 13, 84-95.

[10] Myhren, S. M. (2007). Rural Livelihood and Forest Management in Mount Elgon, Kenya. Master Thesis. Noragric, Department of
International Environment and Development Studies, Norwegian University if Life Science, Norway.

[11] Ogada, M. J., (2012). The New Forest Management Regime in Kenya: Effects on Household Farm Forestry in Kakamega, $18-24$.

[12] Phiri, M. (2009). Evaluation of the Performance of Joint Forest Management ( JFM ) Programme: Case of Dambwa Forest Reserve in Livingstone District , Zambia by, (December).

[13] Tesfaye, Y. (2011). Participatory Forest Management for Sustainable Livelihoods in the Bale Mountains, Southern Ethiopia.

[14] Tesfaye, Y., Roos, A., Campbell, B. J., \& Bohlin, F. (2017) Factors Associated with the Performance of User Groups in a Participatory Forest Management around Dodola Forest in the Bale Mountains , Southern Ethiopia. The Journal of Development Studies ISSN:0022-0388 (Print) 1743-9140 (Online) Journal Homepage: http://www.tandfonline.com/loi/fjds20 Factors, 388(January). https://doi.org/10.1080/00220388.2012.714123 